\title{
The unique skeleton of siliceous sponges (Porifera; Hexactinellida and Demospongiae) that evolved first from the Urmetazoa during the Proterozoic: a review
}

\author{
W. E. G. Müller ${ }^{1}$, Jinhe Li ${ }^{2}$, H. C. Schröder ${ }^{1}$, Li Qiao ${ }^{3}$, and Xiaohong Wang ${ }^{4}$ \\ ${ }^{1}$ Institut für Physiologische Chemie, Abteilung Angewandte Molekularbiologie, Duesbergweg 6, 55099 Mainz, Germany \\ ${ }^{2}$ Institute of Oceanology, Chinese Academy of Sciences, 7 Nanhai Road, 266071 Qingdao, P. R. China \\ ${ }^{3}$ Department of Materials Science and Technology, Tsinghua University, 100084 Beijing, P. R. China \\ ${ }^{4}$ National Research Center for Geoanalysis, 26 Baiwanzhuang Dajie, 100037 Beijing, P. R. China
}

Received: 8 January 2007 - Published in Biogeosciences Discuss.: 6 February 2007

Revised: 10 April 2007 - Accepted: 20 April 2007 - Published: 3 May 2007

\begin{abstract}
Sponges (phylum Porifera) had been considered as an enigmatic phylum, prior to the analysis of their genetic repertoire/tool kit. Already with the isolation of the first adhesion molecule, galectin, it became clear that the sequences of sponge cell surface receptors and of molecules forming the intracellular signal transduction pathways triggered by them, share high similarity with those identified in other metazoan phyla. These studies demonstrated that all metazoan phyla, including Porifera, originate from one common ancestor, the Urmetazoa. The sponges evolved prior to the EdiacaranCambrian boundary (542 million years ago [myr]) during two major "snowball earth events", the Sturtian glaciation (710 to 680 myr) and the Varanger-Marinoan ice ages (605 to $585 \mathrm{myr}$ ). During this period the ocean was richer in silica due to the silicate weathering. The oldest sponge fossils (Hexactinellida) have been described from Australia, China and Mongolia and are thought to have existed coeval with the diverse Ediacara fauna. Only little younger are the fossils discovered in the Sansha section in Hunan (Early Cambrian; China). It has been proposed that only the sponges possessed the genetic repertoire to cope with the adverse conditions, e.g. temperature-protection molecules or proteins protecting them against ultraviolet radiation.

The skeletal elements of the Hexactinellida (model organisms Monorhaphis chuni and Monorhaphis intermedia or Hyalonema sieboldi) and Demospongiae (models Suberites domuncula and Geodia cydonium), the spicules, are formed enzymatically by the anabolic enzyme silicatein and the catabolic enzyme silicase. Both, the spicules of Hexactinellida and of Demospongiae, comprise a central axial canal and

Correspondence to: W. E. G. Müller

(wmueller@uni-mainz.de)
\end{abstract}

an axial filament which harbors the silicatein. After intracellular formation of the first lamella around the channel and the subsequent extracellular apposition of further lamellae the spicules are completed in a net formed of collagen fibers.

The data summarized here substantiate that with the finding of silicatein a new aera in the field of bio/inorganic chemistry started. For the first time strategies could be formulated and experimentally proven that allow the formation/synthesis of inorganic structures by organic molecules. These findings are not only of importance for the further understanding of basic pathways in the body plan formation of sponges but also of eminent importance for applied/commercial processes in a sustainable use of biomolecules for novel bio/inorganic materials.

\section{Introduction}

The origin of the first ancestor of all metazoan phyla remained enigmatic until the identification of first sequences coding for informative proteins from a sponge (phylum Porifera) by application of molecular biological techniques (Pfeifer et al., 1993). Before it had been only speculated that the sponges are true metazoans that are composed of individually reacting and acting cells (see: Pechenik, 2000). With the isolation of the first sponge sequence, a galectin, it became overt that these animals have the genetic toolkit (reviewed in: Pilcher 2005) to allow their cells to differentiate from omnipotent via pluripotent to finally determined somatic cells (reviewed in: Müller, 2006); most of the functional analyses were performed with the sponges Suberites domuncula and Geodia cydonium (see: Müller et

Published by Copernicus GmbH on behalf of the European Geosciences Union. 

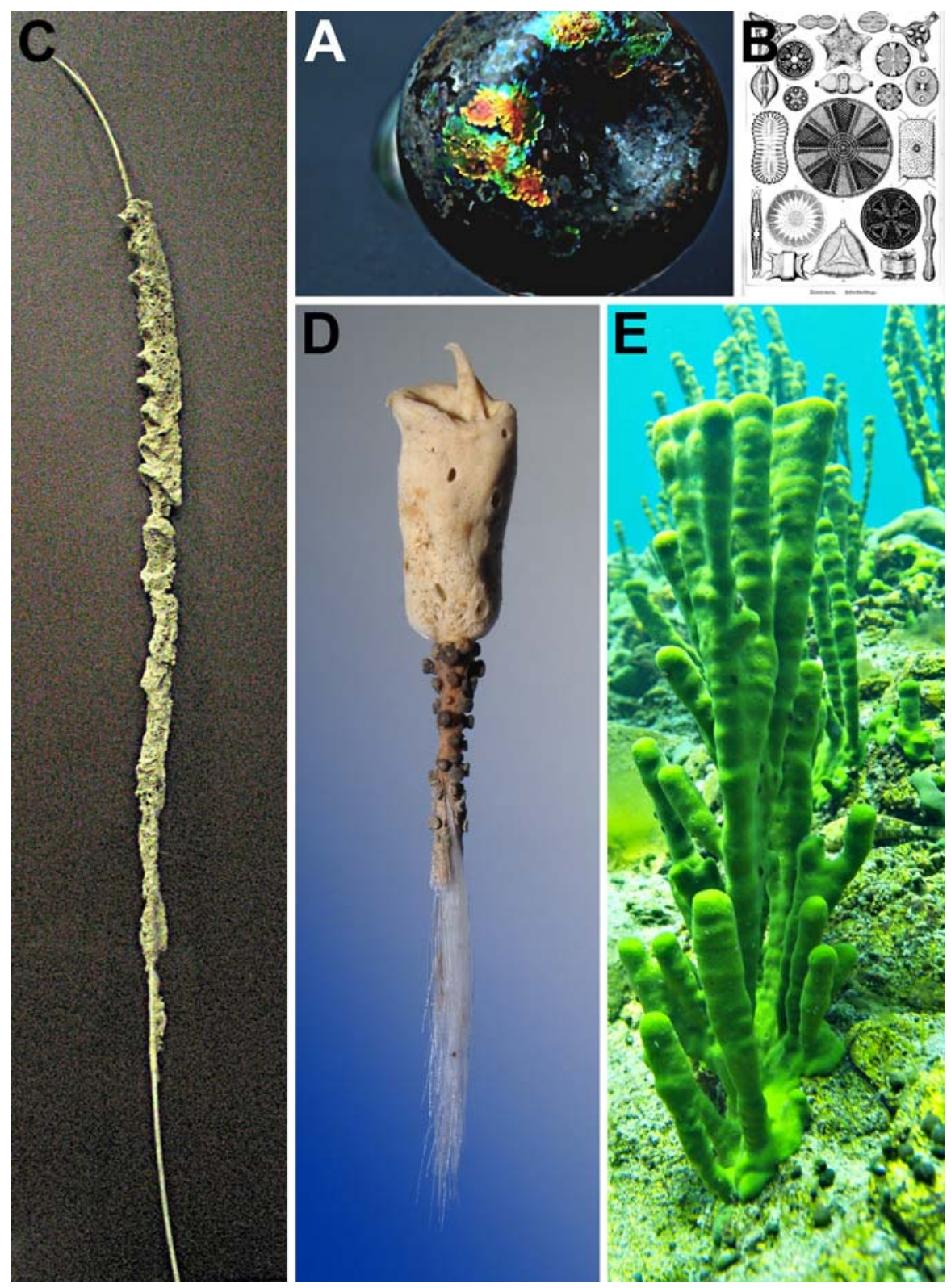

Fig. 1. Non-enzymatic precipitation of silica (A and $\mathbf{B})$ and enzymatic formation of biosilica by sponges (C to $\mathbf{E})$. (A) Roman vase (150 years AC) showing opalescence [silicon-based inorganic films] on the surface of the glass (size: $7 \mathrm{~cm}$ ). (B) Lithography from Haeckel (1899) showing the diverse forms of diatoms. (C) A specimen of Monorhaphis chuni with its giant spicule (height: 1.3 meters) is shown. (D) A Hyalonema species (Hexactinellida), collected by Doflein (1906) (height: $12 \mathrm{~cm}$ ). (E) Lubomirskia baicalensis (Demospongiae), an endemic freshwater sponge from Lake Baikal (height: $40 \mathrm{~cm}$ ).

al., 2004a). With the first cell-matrix adhesion molecule, an integrin (Pancer et al., 1997; reviewed in: Nichols et al., 2006), it could be substantiated that the sponges represent organisms that are composed of cells expressing cell surface molecules allowing their cross talks and in turn also divisions and restrictions of their physiological functions (Müller and Müller, 2003). The individuality of a sponge specimen and the morphogenetic arrangement of its cells according to a defined body plan was underscored by the discovery of apop- totic as well as organizer-specific axis-forming molecules in S. domuncula (reviewed in: Wiens et al., 2004; Müller, 2005; Wiens and Müller, 2006). The next challenge was to understand the environmental factors which drove the evolution of the phylogenetically oldest animals, the sponges. One of the key elements, promoting the emergence of these animals was silicon, which displays both morphogenetic and also structural properties (Krasko et al., 2002). 


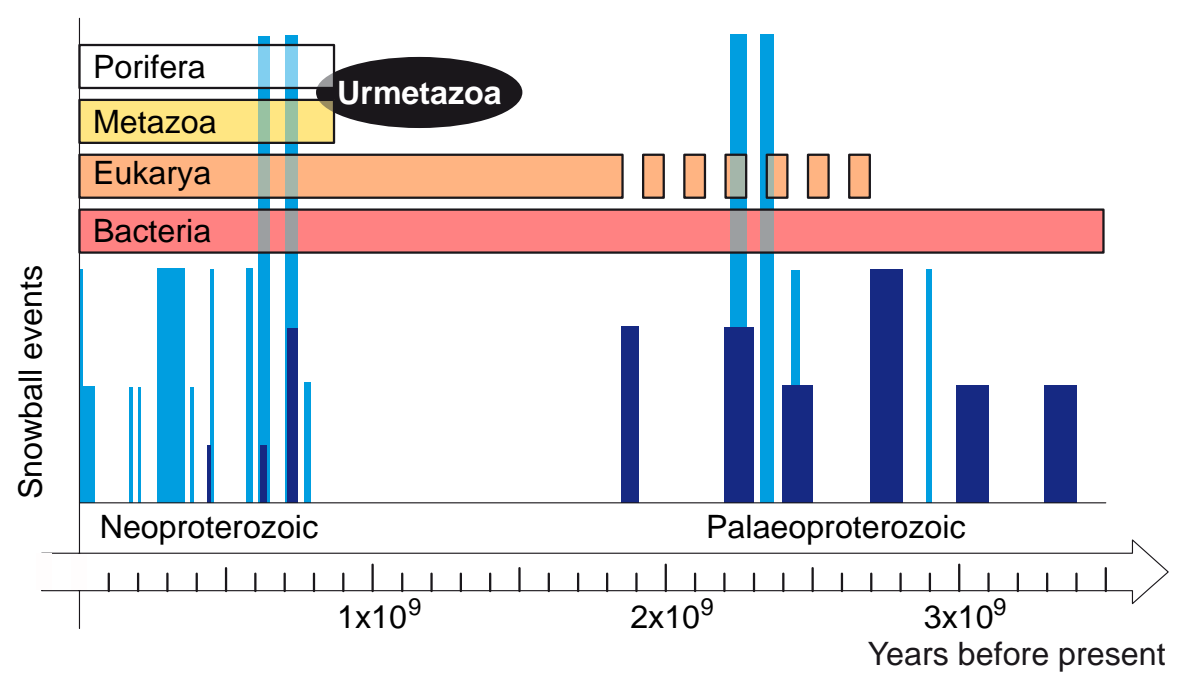

Fig. 2. Frequency of occurrence of major glacial periods (blue). The appearance of the different organismic groups [Bacteria; Eukarya; Metazoa and Porifera] are indicated. The Urmetazoa evolved during the inter-ice period between 600 MA and approximately $800 \mathrm{MA}$ (modified after Hoffmann and Schrag 2002). The light blue bars indicate the major glacial periods, and the dark blue bars the occurrence of "banded iron formation".

\section{Role of silicon and silicate}

Most skeletal structures in Metazoa are composed of calcium-salts, e.g. calcite or apatite. However, as has been found in vertebrates, silica deposition is seen prior to the ossification process forming calcium-apatite bones (Carlisle, 1986). The morphogenetic role of silicon is not restricted to mammals, but has also been identified already in sponges (Krasko et al., 2000). In S. domuncula this element causes especially the expression of genes that are required for the formation of the skeletal elements (Krasko et al., 2002; Müller et al., 2004a; Müller, 2006). Silicon/silica is used in the two sponge classes Hexactinellida and Demospongiae, as starting substrate for the enzymatic synthesis of their silica-based spicules which are the key structures, allowing the formation/arrangement of differentiated cells within an individual according to a body plan (Wiens et al., 2006; Müller, 2006).

Silicon/silicate is usually precipitated passively onto inorganic matrices, e.g. Roman glasses (Fig. 1A), or on organic matrices like in diatoms (Fig. 1B). In sponges, however, the formation of "polymerized"/condensed silicate is governed by an enzyme termed silicatein (Cha et al., 1999). Even after this information is available, it remains to be studied which morphogenetic factors allowed the formation of up to two meters large and highly elaborated sponges, e.g. the hexactinellids Monorhaphis chuni (Fig. 1C) or other hexactinellids like Hyalonema species (Fig. 1D) and also demosponges, e.g. Lubomirskia baicalensis (Fig. 1E). The question arises: When and in which environment did the sponges appear/evolve?

\section{Evolution during the Proterozoic: evolution of sponges in the silicon ocean}

It is surprising that 542 million years ago [myr], near the Ediacaran-Cambrian boundary, a rapid appearance of different animal types occurred. Exciting examples of these emergences were the so-called Ediacaran biota, which are older than the Cambrian animals (Knoll and Caroll, 1999). The development and divergence of the major animal clades were surely driven by the genetic tool kits available at that time. The major, or perhaps even only, metazoan phylum with hard skeleton that existed at the border from Ediacaran to Cambrian (approximately $543 \mathrm{MA}$ ) which did not become extinct are the sponges. Consequently, sponges were also termed "living fossils" (Müller, 1998); they represent the evolutionary oldest, still extant taxon which testifies the developmental level of the animals that lived in the Neo-Proterozoic eon (1000 to 520 MA); Figs. 2 and 3. This must be especially mentioned since two major "snowball earth events" occurred, the Sturtian glaciation (710 to $680 \mathrm{myr}$ ) and the Varanger-Marinoan ice ages ( 605 to $585 \mathrm{myr}$ ), which very likely caused the covering of the earth by a continuous ice layer (Hoffmann and Schrag, 2002). It was proposed that as a consequence of these ice ages most species went extinct, perhaps more than 85\% (Hoffman et al., 1998).

The primordial earth surface comprised initially insoluble silicates and carbonates as well as, to a small extent, phosphates. During the silicate weathering-carbonate precipitation cycle, prior or simultaneously with the glaciations, a dissolution of these surface rocks composed of insoluble silicates $\left[\mathrm{CaSiO}_{3}\right]$ resulted in formation of soluble calcium carbonate $\left[\mathrm{CaCO}_{3}\right]$ and soluble silica $\left[\mathrm{SiO}_{2}\right]$, under 


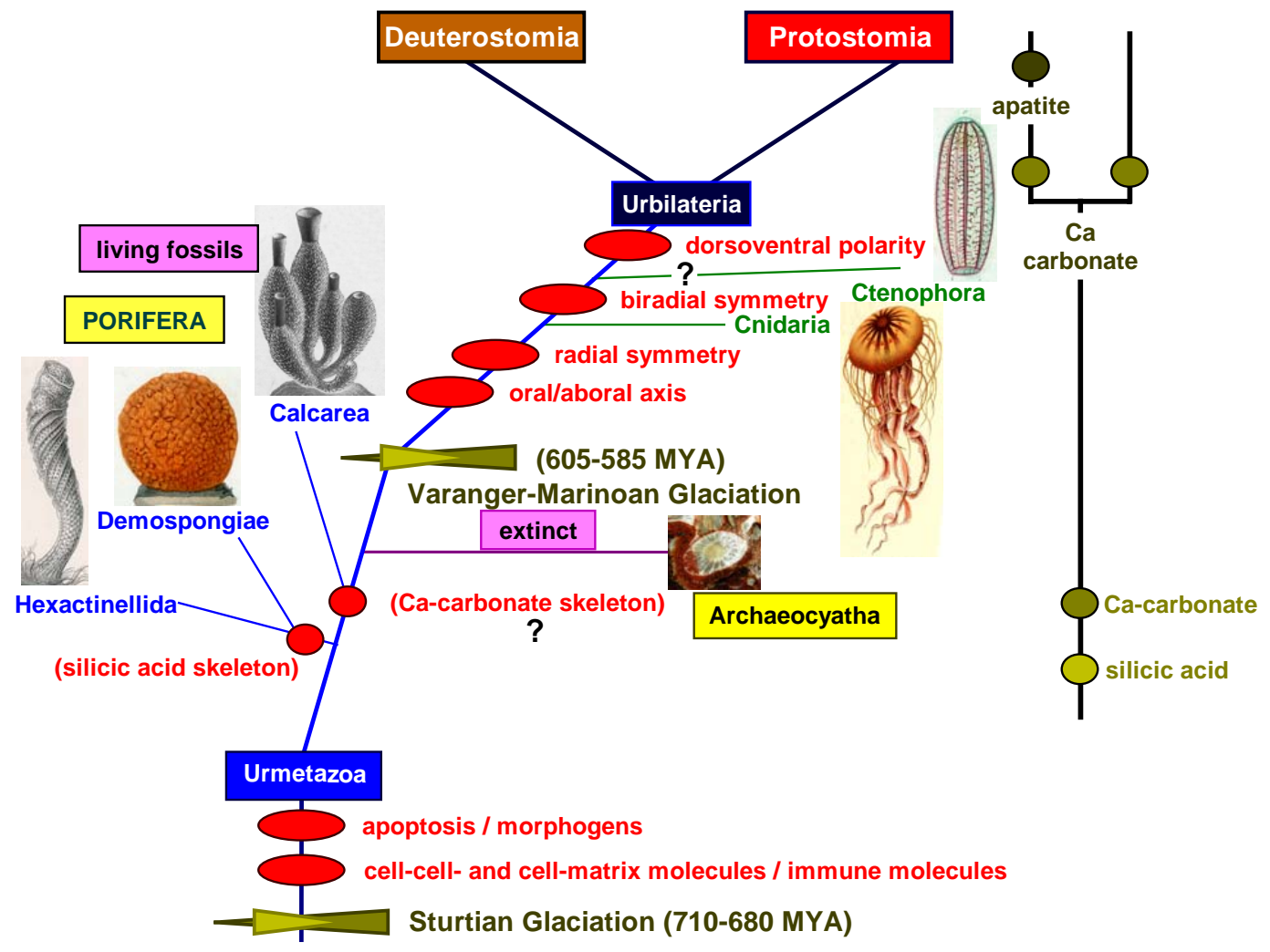

Fig. 3. Phylogenetic position of the Porifera between the Urmetazoa and the Urbilateria. The major evolutionary novelties which have to be attributed to the Urmetazoa are those molecules which mediate apoptosis and control morphogenesis, the immune molecules and primarily the cell adhesion molecules. The siliceous sponges with the two classes Hexactinellida and Demospongiae emerged first and finally the Calcarea, which possess a calcareous skeleton, appeared. These three classes of Porifera are living fossils that provide a reservoir for molecular biological studies. The Archaeocyatha, sponge related animals with a calcareous skeleton, became extinct. The Calcarea are very likely a sister group of the Cnidaria (Schütze et al., 1999). From the latter phylum the Ctenophora might have evolved which comprise not only an oral/aboral polarity but also a biradial symmetry. Finally the Urbilateria emerged from which the Protostomia and the Deuterostomia originated. Very likely the Urmetazoa emerged between the two major "snowball earth events", the Sturtian glaciation (710 to 680 myr) and the Varanger-Marinoan ice ages (605 to 585 myr) (Hoffmann and Schrag 2002); the ice ages are marked (green triangles). In the two poriferan classes Hexactinellida and Demospongiae the skeleton is composed of amorphous and hydrated silica, while the spicules of Calcarea are composed of Ca-carbonate. The latter biomineral is also prevalent in Protostomia and Deuterostomia. In vertebrates the bones are composed of Ca-phosphate [apatite].

consumption of atmospheric $\mathrm{CO}_{2}$ (Walker, 2003). The resulting soluble minerals leached into the waters of the rivers, lakes and oceans. There, they were again re-precipitated into new minerals, as part of the sedimentary rocks. Such processes depend upon temperature, $\mathrm{pH}$ and atmospheric carbon dioxide. Passively, the minerals are transformed diagenetically to secondary structures.

In contrast to passive re-precipitation, biogenic deposition of minerals by metazoans is first seen in sponges. The oldest sponge fossils (Hexactinellida) have been described from Australia, China and Mongolia (from more than 540 MA) (Gehling and Rigby, 1996; Brasier et al., 1997; Li et al., 1998). Hence, the Hexactinellida are the oldest group of sponges as documented there and later in fossil records of the Sansha section in Hunan (Early Cambrian; China; Steiner et al., 1993; Steiner, 1994). In both lower and upper levels of the Niutitang Formation more or less completely preserved sponge fossils, e.g. Solactiniella plumata (Fig. 4A-a to Fig. 4A-c), have been discovered (Steiner et al., 1993). The occurrence of almost intact sponge fossils also in the basal part of this formation is real (Rigby and Guang, 1996) and is stratigraphically equivalent to the Chengjiang assemblage in Yunnan (China). So far the base of the Niutitang Formation has been correlated with the Tommotian black shales, "Badaowan" Member. However, the transgression that deposited the black shale of the Niutitang Formation and the "Badaowan" Member was a diacronous event, which first became evident in the basin environment, Hunan/SE Guizhon/S-Anhui, and progressed across the platform, Yunnan/Sichuan (Steiner, 1994). Therefore, the base of the 

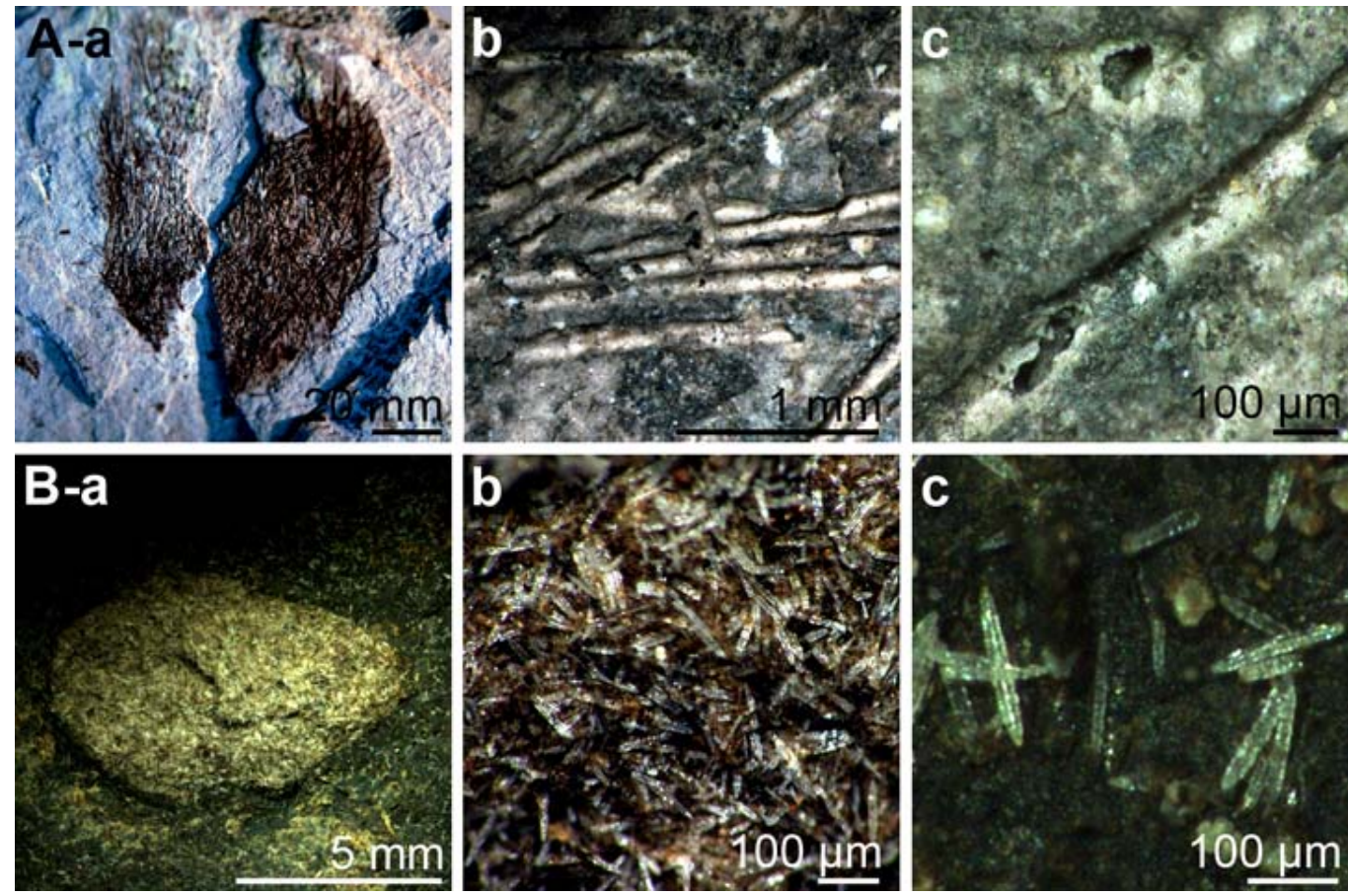

Fig. 4. Fossil marine and freshwater sponge. (A) One of the oldest fossil marine sponge in body preservation are known from the Lowermost Cambrian Sansha section (Hunan, China); Solactiniella plumata (Hexactinellida) (A-a). This fossil is composed of highly intact spicules (A-b). (A-c) Some spicules are broken and expose the internal axial canals. (B) One of the oldest fossil freshwater sponge; Spongilla gutenbergiana from the Middle Eocene (Lutetian) near Messel (Darmstadt, Germany). (B-a) Spicule assembly, reminiscent of a complete animal. (B-b) Oxeas in these nests. (B-c) Oxeas with the flashing centers, representing the axial canals. Size bars are given.

Niutitang Formation, which contains basinal phosphate concretions and cherts, may be correlated with the Tommotian or even the Nemakit-Daldynian. The important point is that the sponges at the Sansha section definitely occur at lower levels than the famous, diverse fauna at Chengjiang. Except for one questionable demosponge, all the sponges described from the Sansha section can be attributed to the Hexactinellida.

Very likely the oldest isolated spicules were also found in China, observed in thin sectioned material from the Dengying Formation, "Shibantan" Member, Hubei Province (Steiner et al., 1993). These spicules are mainly monaxial spicules, but some are also rather definite "crosses", the evidence of triaxones from hexactinellids. The "Shibantan" Member in Hubei is of Late Proterozoic age and stratigraphically equivalent with the Ediacara (South Australia), which is famous because of its exceptionally preserved Vendian fossils. The Ediacara fauna has normally been considered to begin at about $600 \mathrm{MA}$, although new stratigraphic data place the base of the Ediacara fauna at $\approx 565 \mathrm{MA}$, and suggest that it ranges up to the Precambrian/Cambrian boundary (Grotzinger et al., 1996). Still, the Ediacara-type Vendian fossils are the oldest megafossils which may, at least partly, be interpreted as metazoans, although this interpretation is still controversial (Seilacher, 1989; Morris, 1993; Morris, 1994; Retallack, 1994). It is thus justified to call the Porifera the oldest organismic group in the Earth's history, which can now be proven as definitely belonging to the animal kingdom, and which furthermore has survived successfully until present times. In contrast, to the marine Hexactinellida and Demospongiae, the freshwater demosponges are much younger; one of the first fossil freshwater sponges, Spongilla gutenbergiana, has been described from the Middle Eocene (Lutetian); (Müller et al., 1982; Fig. 4B-a to Fig. 4B-c).

The earliest evidence of demosponge fossils have been found in 750 my old strata of Nevada (Reitner and Wörheide, 2002). Hence, the records of Demospongiae and Calcarea presence of isolated spicules in thin sections of rocks from Early Cambrian (Atdabatian) Archaeocyath mounds of the Flinders Ranges (South Australia) (reviewed in: Li et al., 1998) are younger. The Calcarea documented from the Flinders Ranges Archaeocyath mounds are both, isolated spicules and also more or less complete rigid skeletons of small calcaronean sponges sitting on Archaeocyaths. It had been suggested that a fourth class of sponges, the Sclerospongiae, exists composing both siliceous and calcareous skeletal elements; however these "coralline sponges" apparently have arisen several times and are not closely related. The spicules are of the triaene, equal-angular type characteristic of the modern Calcarea, but quite different from those typical of the Paleozoic Heteractinellida. Very similar, perhaps identical, spicules were described from the Early 
Cambrian of Sardinia as Sardospongia triradiata and attributed to the Heteractinellida (Mostler, 1985). The complete calcarean sponge Gravestockia pharetronensis (Reitner, 1992) from the Flinders Ranges possessed a rigid calcitic skeleton with affinity to the modern Pharetronida. As one of the earliest families of demosponges the Geodiidae have been described on the basis of their sterrasters (Reitner and Mehl, 1995).

Those taxa that survived the "snowball earth" episodes must have had the genetic repertoire to cope with the adverse conditions, meaning: (i) proteins to protect against adverse temperature, (ii) possibility to survive food restriction and (iii) - not to forget - also the protection machinery against ultraviolet radiation. During the pre-Sturtian period, atmospheric $\mathrm{CO}_{2}$ had been consumed and removed from the atmosphere resulting in extreme temperature amplitudes. Sponges have cryoprotective proteins, e.g. galactosespecific lectins (Pfeifer et al., 1993; Wiens et al., 2003) which display cryoprotective protein-membrane activity, or, interestingly, also $\beta \gamma$-crystallins, proteins that contain only low amounts of water and hence are resistant to adverse protein folding (Krasko et al., 1997). Food restriction was probably compensated by the establishment of a symbiotic relationship with microorganisms (Müller et al., 2004b), such as gram-positive (Thakur et al., 2005) and gram-negative bacteria (Wiens et al., 2005) as well as fungi (PerovicOttstadt et al., 2004a). This eukaryotic-prokaryotic "labordivision" allowed the sponges a flexible and rapid adaptation to the changing environment. It is furthermore amazing that sponges have an unexpected variety of protection systems against mutagens, including also ultraviolet radiation. Several protection systems against radiation have been described; e.g. the (6-4) photolyase system (Krasko et al., 2003b) or the SOS-response-like mechanism (Krasko et al., 1998), and numerous is the literature on protection systems against environmental stress (e.g. Efremova et al., 2002). Perhaps the greatest fortune for the sponges was their ability to utilize silicic acid as substrate for their skeleton. When sponges emerged, the insoluble silicate minerals were converted into monomeric, soluble silica providing the sponges with an advantageous basis for survival and diversification, with respect to the number of the species and their abundance. In this context it should be mentioned that with the diversification and evolution of sponges (at least valid for endemic freshwater species) an increase in the gene number for silicateins occurred (Müller et al., 2006d). Early assumptions postulated that those taxa which survived mass extinction, e.g. the Foraminifera, became ecological and morphologically generalized species (Cifelli, 1969). Furthermore, the number of species, the diversity of the biota, increased rapidly after each period of extinction (Futuyma, 1986). Hence, the sponges (survivor taxon) became the beneficiaries of the glaciation crises and received the chance to colonize those habitats which had been de-populated (see also: Butterfield, 2007).
The urmetazoans/sponges (Müller et al., 2001) had already the basic genetic toolkit for all derived metazoans which emerged during the "Cambrian Explosion" (Figs. 2 and 3). This statement implies that the genetic repertoire of the sponges, which survived the glaciations, gave the frame, potentials/potentialities but also the limits of the body plan construction seen in higher derived taxa and which exist in the present day animal phyla. The derived taxa utilized the pre-existing molecules and pathways for their diversification of patterning and for an increase in the genetic network complexity. It can be postulated that during the progress of evolution the degree of redundancy decreased on the expense of an increase in complexity. This progressive "perfection" might be detrimental to the stability and survival of most of the species which are evolutionary younger.

The oxygen level in the atmosphere and in the water during the early Proterozoic was lower than at present (Towe, 1970; Hayes, 1994). It had been postulated that with the rise of oxygen level the synthesis of collagen became possible (Towe, 1981); sponges contain and express collagen genes (Garrone, 1998). The ability to form these extracellular fibrils had been considered to be a crucial prerequisite for the origin of multicellular animals and the establishment of a metazoan body plan (Towe, 1981). Until now, no experimental evidence for an existence of a primordial, blood oxygentransporting system in sponges has been found. Therefore, we assume that most of the oxygen required by these animals to allow intermediary metabolism is provided by diffusion. Perhaps oxygen is partly transported/generated via the tyrosinases (Müller et al., 2004b). However, this apparent disadvantage was surely of benefit for the sponges to survive the oxygen deficiency in waters because of an ice cover during the glaciations.

\section{Unique formation and degradation of biosilica in sponges: silicatein and silicase}

Sponges are sessile filter-feeding organisms; their body is composed of an epithelial layer which surrounds a mesohyl compartment; this is reticulated in a highly organized manner by a canal system. The main structural and functional novelties, which evolved during the major evolutionary transitions to the Porifera, are summarized in Fig. 3. One characteristic trait of the demosponges and hexactinellids sponges are the spicules (the sclerocytes) which stabilize the sponge bodies and provide the platform on which the body plan can develop (reviewed in: Müller et al., 2004a). In the center of the spicules is a hollow canal of varying diameter around which the silica is deposited under formation of concentric layers (Uriz et al., 2000; Uriz et al., 2006). An organic filament, called axial filament, around which the axial canal had been formed is composed of the enzyme silicatein (Fig. 5). Interestingly, the spicules with their characteristic features, the axial canals, can be identified 
in fossil sponges (Fig. 4A-c). The inorganic silica phase of the siliceous spicules contains $6-13 \%$ water, yielding an approximate formula of $\left(\mathrm{SiO}_{2}\right)_{2-5} \cdot \mathrm{H}_{2} \mathrm{O}$ (reviewed in: Sanford, 2003). High resolution magnetic resonance microimaging studies revealed that this water is largely present in a "mobile" form at least in certain freshwater sponges (Müller et al., 2006b). In addition, spicules contain trace amounts of other elements, mainly $\mathrm{S}, \mathrm{Al}, \mathrm{K}$, and $\mathrm{Ca}$, but also $\mathrm{Cl}, \mathrm{Fe}, \mathrm{Na}$, $\mathrm{Zn}$, and $\mathrm{Cu}$ (reviewed in: Uriz et al., 2003; Sanford, 2003).

One major breakthrough in the understanding of spicule formation came after the discovery of the key enzyme involved. The group of Morse discovered that the organic filament in the central axial canal of spicules is composed of a cathepsin L-related enzyme, which they termed silicatein (Shimizu et al., 1998; Cha et al., 1999); Fig. 5. They cloned two of the proposed three isoforms of silicateins, the $\alpha$ - and $\beta$-forms, from the marine demosponge Tethya aurantium (Cha et al., 1999). In subsequent years these molecules were cloned also from other sponges, among them the marine sponge Suberites domuncula and the freshwater sponge Lubomirskia baicalensis (Schröder et al., 2004b; Wiens et al., 2006).

From $S$. domuncula the cDNA encoding silicatein was isolated and characterized; the predicted translation product of 330 amino acids has a calculated size of $M_{r} 36306$. Silicatein is a new member of the cathepsin subfamily (Cha et al., 1999; Müller et al., 2003; Müller et al., 2005). The three amino acids Cys, His and Asn, which form the catalytic triad of cysteine proteases, are present in the sponge cathepsin at the characteristic sites: $\mathrm{Cys}_{125}$, His 164 and $\mathrm{Asn}_{184}$. Furthermore, silicatein comprises one cluster of characteristic hydroxy amino acids (serine). We could demonstrate that silicatein occurs in the axial filament in several isoforms (Schröder et al., 2004b) and by two-dimensional gel electrophoretic analysis of the axial filament (silicatein) we could show that in this compartment silicatein undergoes stepwise phosphorylation.

A further enzyme of potential interest for application in nanobiotechnology is the silicase. This enzyme is able to depolymerize amorphous silica (Schröder et al., 2003a). The cDNA encoding the silicase has been identified in primmorphs from $S$. domuncula, applying the technique of differential display of transcripts. The expression of the silicase gene is strongly upregulated in response to higher silicon concentrations in the incubation assays (Schröder et al., 2003b), like the expression of silicatein. The deduced polypeptide has an $M_{r}$ of 43131 . Silicase is a member of the family of carbonic anhydrases. An alignment of the sponge silicase sequence with the human carbonic anhydrase II shows that most of the amino acids which are characteristic for the eukaryotic-type carbonic anhydrase signature are also present in the sponge silicase (Schröder et al., 2003b). The recombinant silicase was found to display besides carbonic anhydrase activity the ability to dissolve amorphous silica under formation of free silicic acid (Schröder et al., 2003b).

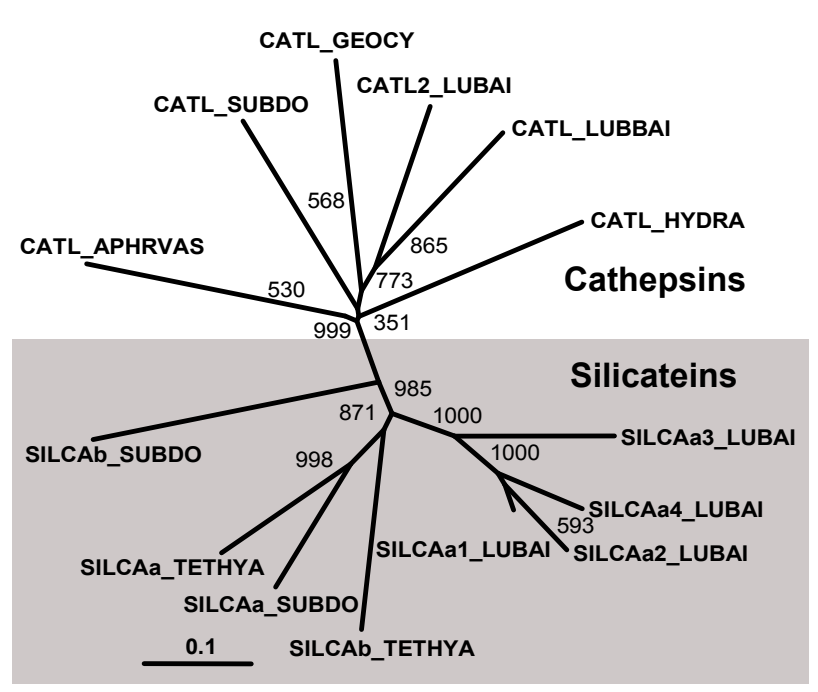

Fig. 5. Phylogenetic relationship of the silicateins, the enzyme which catalyzes the polymerization process of biosilica in the sponge spicules. Four deduced silicatein sequences of the isoform silicatein- $\alpha[\alpha-1, \alpha-2, \alpha-3$ and $\alpha-4]$ from Lubomirskia baicalensis (SILICAa1_LUBAI; SILICAa2_LUBAI; SILICAa3_LUBAI; SILICAa4_LUBAI) and the two cathepsin L sequences (CATL_LUBAI; CATL2_LUBAI) were aligned with silicatein- $\alpha$ from $S$. domuncula (SILICAa_SUBDO) from Tethya aurantia [T. aurantium] (SILICAa_TETYA) and with the $\beta$-isoenzymes from $S$. domuncula (SILICAb_SUBDO) and Tethya aurantium (SILICAb_TETYA), as well as with the cathepsin L sequences from sponges Suberites domuncula (CATL_SUBDO), Geodia cydonium (CATL_GEOCY, Y10527) and Aphrocallistes vastus (CATL_APHRVAS) as well as from the cnidarian Hydra vulgaris (CATL_HYDRA; AAO65603). An unrooted phylogram was constructed after the alignment of these sequences. The numbers at the nodes are an indication of the level of confidence for the branches as determined by bootstrap analysis (1000 bootstrap replicates).

Carbonic anhydrases are a family of zinc metal enzymes (Sly and Hu, 1995). In the S. domuncula silicase the three conserved His residues which bind the zinc ion are found in the deduced protein at $\mathrm{aa}_{181}, \mathrm{aa}_{183}$ and $\mathrm{aa}_{206}$. The proposed mode of action of the silicase to depolymerize amorphous silica follows the reaction mechanism known for other zincdependent enzymes involved in ester hydrolysis. The zinc ion is a Lewis acid that interacts with water, a Lewis base. The zinc-bound hydroxide ion formed by splitting the water molecule mediates a nucleophilic attack at one of the silicon atoms linked by oxygen bond(s). In the next step the zinc-complex binds, within the polymeric silicate, to one silicon atom under cleavage of the oxygen linkage. Through consumption of $\mathrm{H}_{2} \mathrm{O}$, the silicic acid product is released and the zinc-bound hydroxide is regenerated allowing the start of the next catalytic cycle. The enzyme has been expressed in Escherichia coli using the glutathione S-transferase (GST) fusion system (Schröder et al., 2003b). 

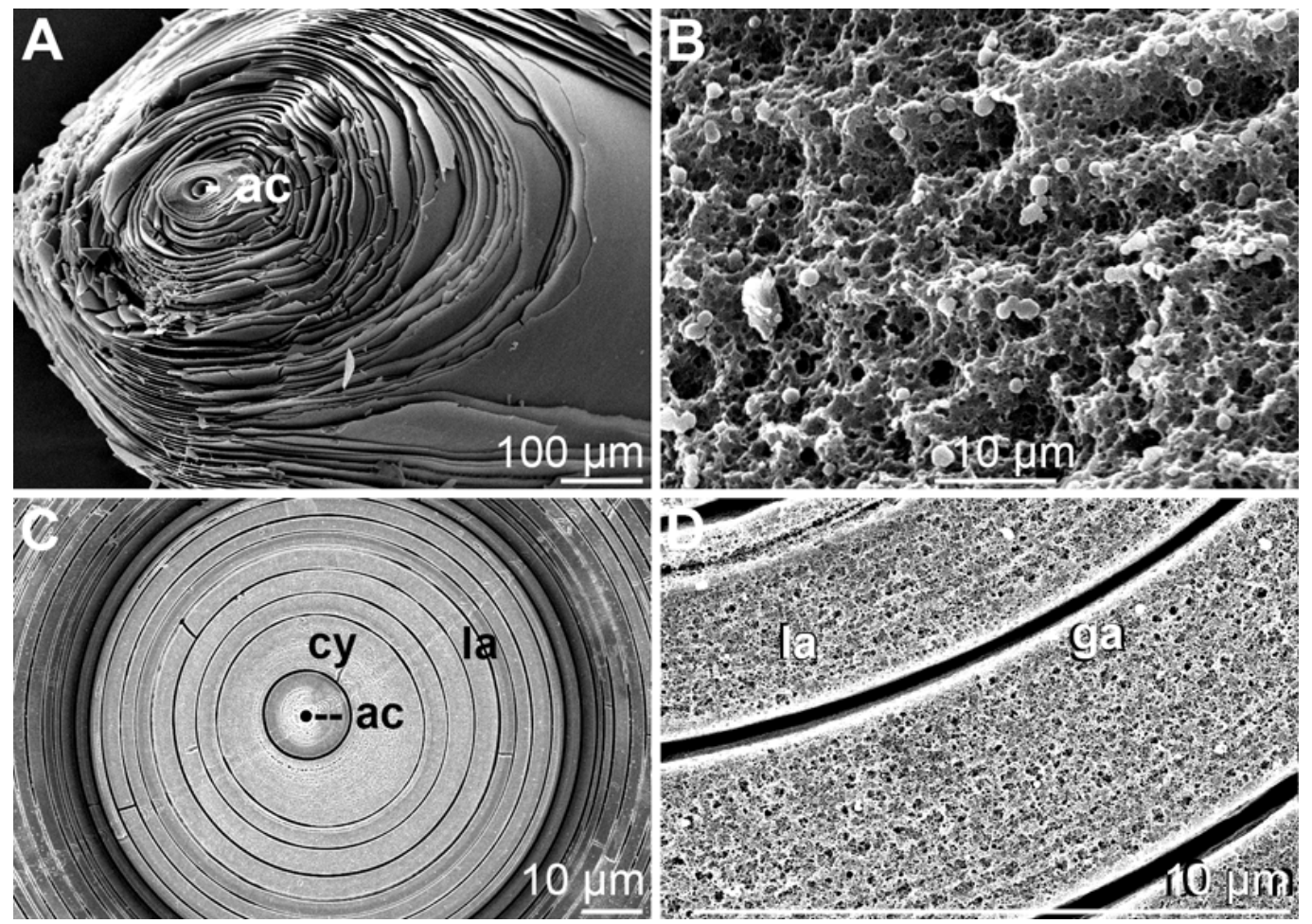

Fig. 6. Morphology of hexactinellid spicules. Concentric organization of the silica layers of giant spicules and giant basal spicules from Monorhaphis intermedia (A to D). (A) The diagonal scanning electro micrograph (SEM) shows the layered surface of the spicules. The layers are separated by small gaps, which harbored the proteinaceous material, synthesizing the silica layers. (B) Granules and spheres of silica which form the lamellae of the spicules. (C and D) Giant basal spicules (basalia) from M. intermedia. The polished cross sections can be divided in three parts: (i) The axial canal (ac) in which the axial filament is located. (ii) An axial cylinder (cy), formed by dense homogeneous silica and finally (iii) the main part of the spicule with the regularly arranged concentric silica lamellae (la). (D) Higher magnification of the lamellar region is shown. Between the lamellae (la) a gap (ga) exists.

Recent studies have shown that during spicule formation in primmorphs of $S$. domuncula, the expression of both enzymes, silicatein and silicase, is seen at those sites within the 3D-cell aggregates where the growth/formation of the siliceous structures starts (Eckert et al., 2006). The role of the silicateins as synthesizing enzymes also in vivo was elucidated by in situ hybridization studies (Schröder et al., 2004a). In a recent study immunofluorescence analyses have been applied to demonstrate that in primmorphs silicatein is associated with fibrous structures in primmorphs that represent the primordial spicules. In parallel with the application of antisilicatein it could be shown that also the silica catabolizing enzyme [silicase] is localized at the same structures within the primmorphs. This result had been supported also by immunofluorescence studies of sections through tissue samples.

\section{Hexactinellida: first approaches to understand spicule formation}

The monophyletic group of Hexactinellida is, according to the form and organization of its spicules, divided into two subclasses, Hexasterophora and Amphidiscophora. One member of this subclass is the family Monorhaphididae which includes also the three species - Monorhaphis chuni, $M$. dives and $M$. intermedia. Since the discovery of these sponges during the first German Deep Sea Expedition (RV "Valdivia") and the first descriptions of these animals by Chun (1900) and Schulze (1904), only little additional information has been added about the form and construction of their skeletal systems. Nothing has been published about the synthesis of their giant spicules. Worldwide M. chuni has been documented only at few sampling sites, suggesting a distribution in the deep sea in the Indian Ocean and in the West Pacific. One outstanding feature of Monorhaphis is the anchoring spicule which can reach lengths of up to $3 \mathrm{~m}$ with a maximum diameter of $8.5 \mathrm{~mm}$ (Schulze, 1904). M. chuni thus produces the largest biosilica structure known on Earth. Polished cross sections confirm the existence of up to 500 highly regular concentric rings which are arranged around a $150 \mu \mathrm{m}$ thick, less structured core (Schulze, 1904). In the middle of this core, a square axial channel with an approx. $2 \mu \mathrm{m}$ thick proteinaceous filament is visible, which 
runs through the entire spicule from one end to the other (Fig. 6A, C and D). The silica layers are composed of smaller granules and spheres within a network of (perhaps) proteinaceous material (Fig. 5B).

An additional hexactinellid Hyalonema sieboldi likewise possesses long stalk spicules that attach them to the substratum; the animals live in a depth of more than 600 fathoms (1000 m); (Wyville Thomson, 1874 and also Müller et al., 2006c). The long stalk spicules are composed of distinct siliceous layers which are also superposed in a stratified pattern around a central axial filament (Schulze, 1904). It could be demonstrated that these giant spicules from the root-tuft of $H$. sieboldi transmit light with high efficiency. Surprisingly, however, the blue light with a wavelength between 400 and $600 \mathrm{~nm}$ is filtered out. Data elaborated in our group suggest that the spicules from $H$. sieboldi act as optical absorbent in a novel photoreception system (Müller et al., 2006c).

Very recently, Aizenberg et al. (2005) published a detailed structural analysis of the spicule formation in the hexactinellid Euplectella. They demonstrated structural hierarchies of the spicule synthesis starting from the nanometer-sized particles of silica to the final mature spicules. The compositions of the proteins which are associated with and found in the spicules have not been described. In a recent study Ehrlich et al. (2005) dissolved the basal spicules of the hexactinellid $H$. sieboldi in alkaline solution for 14 days and showed that the abundant structural protein, associated with the spicules might be collagen.

We performed microscopic analyses of the spicules from $M$. chuni with major emphasis of the large-sized giant spicules (giant basal spicules or basalia; size of $1 \mathrm{~m}$ ) and also the large comitalia (small di- or tri-actine spicules of a size of around $60 \mathrm{~mm}$ ). The focus of the study was put on the organic components of these spicules, including the collagen fibrils which surround them. Electron microprobe analysis data show a regionally different distribution of sodium and potassium within the spicules. With respect to the organic components, it should be highlighted that after dissolution of the spicules several proteins could been visualized; $(i)$ one of them cross-reacted with antibodies raised against silicatein (Wang et al., 2007; Müller et al., 2007), while (ii) others displayed proteolytic activity (to be published).

After having substantiated, by application of molecular biological techniques, that also Hexactinellida have at least one gene coding for collagen (the cDNA was isolated from the hexactinellid Aphrocallistes vastus) a schematic outline of spicule growth both in longitudinal and transversal direction could be given (Fig. 7). In the center of the spicules the axial canal is filled with an axial filament whose protein composition is highly similar to that described for demosponges. After formation of a first silica layer, assumed to be the result of silicatein or of a silicatein-related protein, the next layer is formed through centrifugal and centripetal synthesis of a silicatein(-related) protein. In analogy to Demospongiae (Schröder et al., 2006) it is adopted that the silicatein(-

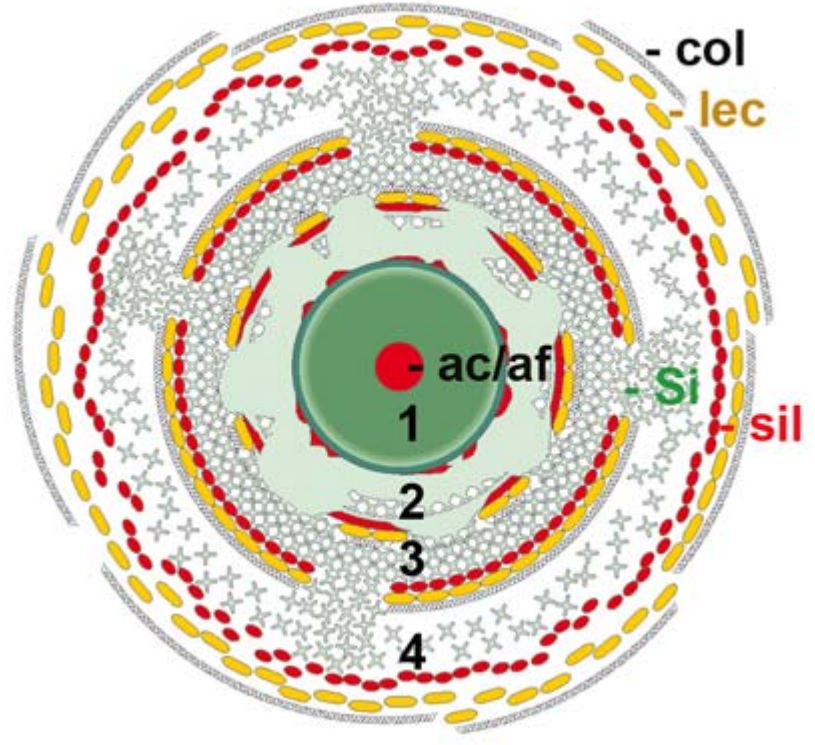

Fig. 7. Proposed schematic illustration of the spicule formation in the hexactinellid $M$. chuni and $M$. intermedia. The center of the spicule comprises the axial canal (ac) which is filled with the axial filament (af; in red). Around the axial filament a first lamella has been formed (1). The formation of the next silica lamella is supposed to be mediated by silicatein(-related) proteins (red ellipsoid balls) which are arranged both on the surface of the first lamella and a proteinaceous tube/cage which is stabilized in its outer layer by lectin molecules (yellow balls). The final orientation of the tube is provided by the collagen mat. Within the cage a solid silica lamella is formed through an association of the silica clusters. The concentric arrangement of the silicatein(-related) proteins/lectin associates is proposed to be stabilized by collagen (col; grey fibers).

related) protein is associated with a lectin which forms a tube-like cage around the existing silica lamella. After deposition of newly formed silica clusters followed by a solid silica lamella the existing proteins are hydrolyzed by protease(s). In continuation a third lamella of silica is formed. The model also proposes that collagen guides the silicatein(related) protein/lectin associates concentrically along the spicules.

\section{Demospongiae: silica deposition during spicule for- mation}

The biochemical basis for the understanding of the morphology of the spicules has been analyzed recently using the marine demosponge $S$. domuncula (reviewed in: Müller et al., 2006a). From this species primmorphs were prepared and applied for the analysis of spicule formation. Primmorphs, a special type of 3D-cell aggregates, containing proliferating and differentiating cells, allow to study the differentiation of archaeocytes to sclerocytes during incubation in medium supplemented with silicic acid. The spicules were analyzed 

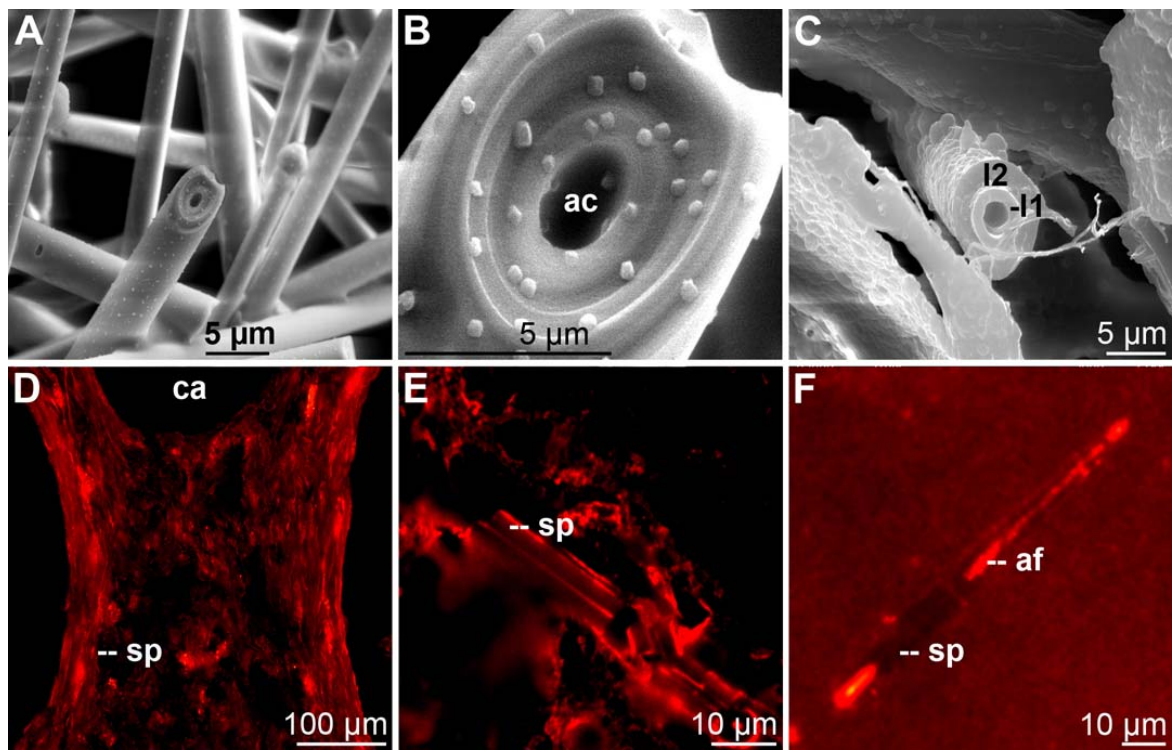

Fig. 8. Morphology of demospongian spicules showing the zonation of the silica shell of the spicules from Suberites domuncula. (A to C) SEM analysis of broken spicules in primmorphs, after an incubation period of 20 days. Around the axial canal (ac) two layers of lamellae (11 and 12) can be distinguished. In B the spicule have been etched order to visualized the lamellae. (C and D) Immunostaining of spicules with antibodies, raised against silicatein (PoAb-aSILIC). (D) Immunostaining of cryosections through tissue of $S$. domuncula. 8- $\mu$ m thick frozen sections were reacted with polyclonal silicatein antibodies. Spicules (sp) and one canal of the aquiferous system (ca) are marked. (E and F) Reaction of antibodies against silicatein with partially digested (hydrofluoric acid) spicules. The preparations were placed onto glass slides and treated with the antibodies. (F) The immuno-stained specimen showed that both the surface of the spicules (sp) and also the axial filaments (af) were brightly stained.

by electron microscopical procedures, e.g. scanning electron microscopy (SEM) analysis of spicules, transmission electron analysis (TEM) and electron immunogold labeling. The skeleton of $S$. domuncula is composed of only two types of megascleres, monactinal tylostyles and a smaller fraction of diactinal oxeas. The spicules reach up to $450 \mu \mathrm{m}$ in length and diameters of 5 to $7 \mu \mathrm{m}$ (Fig. 8A to C); they grow through apposition of lamellar silica layers. While the two ends of the oxeas are pointed, the tylostyles have one pointed end and one swollen knob. All spicules have an axial canal of 0.3 to $1.6 \mu \mathrm{m}$ in width in the center. As shown in SEM images (Fig. 8A to C) the central canal is surrounded by lamellated layers approximately 0.3 to $1 \mu \mathrm{m}$ thick. To monitor the location and distribution of silicatein in and around the spicules, polyclonal antibodies were raised against purified filaments from spicules in rabbits (Müller et al., 2005). Immunofluorescence studies with cryosections through tissue revealed that the surfaces of the spicules in the tissue (Fig. 8D) and of isolated spicules (Fig. 6E and F) are surrounded by silicatein. From these studies we conclude that silicatein is not only present in the axial filament of the spicules, but is also located on their surface.

According to our results the process of spicule formation should be divided into the following phases; the initial intracellular steps and the extracellular final and shaping phase (Müller et al., 2006a and Eckert et al., 2006). (i) Intracellular phase: Silica is taken up actively by a $\mathrm{Na}^{+} / \mathrm{HCO}_{3}^{-}\left[\mathrm{Si}(\mathrm{OH})_{4}\right]$ cotransporter. Very likely during the transport through the endoplasmic reticulum and the Golgi complex, silicatein undergoes phosphorylation and is transported into vesicles where it forms rods, the axial filaments (Fig. 8A); around them the first layer(s) of silica is (are) formed. Silica deposition occurs in two directions; first from the axial canal to the surface (centrifugal orientation) and second from the mesohyl to the surface of the spicule (centripedal). Finally the spicules are released into the extracellular space where they grow in length and diameter by appositional growth (Fig. 8B)

(ii) Extracellular phase (appositional growth): Silicatein is present also in the extracellular space. It came surprising that also there the silicatein molecules are organized to larger entities. Immunogold electron microscopical analysis showed that the silicatein molecules are arranged along strings, which run parallel to the surfaces of the spicules (Schröder et al., 2006). In the presence of $\mathrm{Ca}^{2+}$, silicatein associates with galectin and allows the appositional growth of the spicules (Fig. 8B). Since the surface of a new siliceous spicule is also covered with silicatein, the appositional growth/thickening of a spicule hence proceeds from two directions (centrifugal and centripetal).

(iii) Extracellular phase (shaping): In the next step, the galectin-containing strings are organized by collagen fibers 


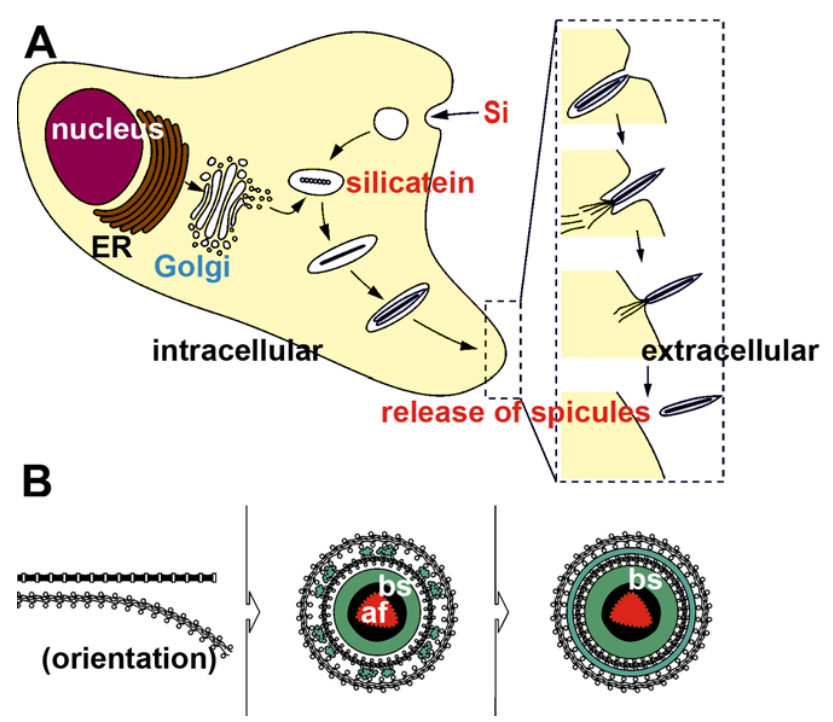

Fig. 9. Schematic outline of spicule formation in S. domuncula. (A) The initial steps of spicule synthesis occur intracellularly where the silicatein is processed to the mature form. During this processing the silicatein undergoes phosphorylation. Very likely with the help of other proteins the silicatein molecules assemble to a rod, the axial filaments. Around this filament the first deposition if silica proceeds. (B) Process of the appositional growth of the spicules in the extracellular space (mesohyl). In the mesohyl, galectin molecules associate in the presence of $\mathrm{Ca}^{2+}$ to strings [nets] that allow binding of silicatein molecules. Collagen fibers orient the silicateingalectin strings concentrically round the growing spicules. In the last step, biosilica deposition is mediated in two directions, originating both from the silicatein-galectin strings and from the surface of the spicules (centripetal and centrifugal). Finally an additional further biosilica lamella (bs) is formed which is layered onto the previous two lamellae. The initial biosilica layer is formed around the silicatein rod, existing in the axial canal (ac) of the spicules.

to net-like structures. It is very likely that collagen which is released by the specialized cells, the collencytes, provides the organized platform for the morphogenesis of the spicules. The longitudinal growth of the spicules can be explained by the assumption that at the tips of the spicules, the galectin/silicatein complexes are incorporated into deposited biosilica under formation and elongation of the axial canal/filament.

\section{Change in a paradigm}

In 1828 Wöhler succeeded to copy nature by producing an organic compound from inorganic reactants. He synthesized urea from the inorganic ammonium cyanate, establishing the first rules in organic chemistry. However, to copy organic (bio)synthetic reactions comprehensively, the existence of enzymes had to be discovered, an important step which dates back to Pasteur (1857). He discovered that lac- tic acid is a fermentation product, and thus proved the basis for the discipline biochemistry. The causal-analytical understanding of organic reactions in biological systems became possible after the deciphering of the genetic code and the subsequent elucidation and application of molecular biological, recombinant techniques. It took, however, until recently when first strategies had been formulated and experimentally proven, to outline the biosynthesis of inorganic structures formed in uni- and multicellular organisms. At present, in a self-accelerating progress, the matrices (templates), e.g. collagen, and the organic catalysts (enzymes), e.g. silicatein, required for the synthesis of those inorganic structures and skeletal elements have been illuminated with the help of inorganic/organic chemists, biochemists, molecular biologists and material scientists, to establish the discipline "bio-inorganic material science". The first opportunities have been touched in biomedicine and electronics providing us with the chances, power and potential of silicatechnology (see: Schröder et al., 2007 and Wang et al., 2007).

Acknowledgement. This work was supported by grants from the European Commission, the Deutsche Forschungsgemeinschaft, the Bundesministerium für Bildung und Forschung Germany (project: Center of Excellence BIOTECmarin), the National Natural Science Foundation of China (No. 50402023) and the International Human Frontier Science Program.

Edited by: W. Kiessling

\section{References}

Aizenberg, J., Weaver, J. C., Thanawala, M. S., Sundar, V. C., Morse, D. E., and Fratzel, P.: Skeleton von Euplectella sp.: structural hierarchy from nanoscale to the macroscale, Science, 309, 275-278, 2005.

Brasier, M., Green, O., and Shields, G.: Ediacarian sponge spicule clusters from southwest Mongolia and the origins of the Cambrian fauna, Geology, 25, 303-306, 1997.

Butterfield, N. J.: Macroevolution and macroecology trough deep time, Palaeontology, 50, 41-55, 2007.

Carlisle, E. M.: Silicon as an essential trace element in animal nutrition, Ciba Foundation Symposium 121, John Wiley, Chichester, 123-136, 1986.

Cha, J. N., Shimizu, K., Zhou, Y., Christianssen, S. C., Chmelka, B. F., Stucky, G .D., and Morse D. E.: Silicatein filaments and subunits from a marine sponge direct the polymerization of silica and silicones in vitro, Proc. Natl. Acad. Sci. USA, 96, 361-365, 1999.

Chun, C.: Aus den Tiefen des Weltmeeres, Gustav Fischer, Jena, 1900.

Cifelli, R.: Radiation of Cenozoic planktonic Foraminifera, Syst. Zool., 18, 154-168, 1969.

Doflein, F.: Ostasienfahrt, B. G. Teubner, Leipzig, 1906.

Eckert, C., Schröder, H. C., Brandt, D., Perovic-Ottstadt, S., and Müller, W. E. G.: A histochemical and electron microscopic analysis of the spiculogenesis in the demosponge Suberites domuncula, J. Histochem. Cytochem., 54, 1031-1040, 2006. 
Efremova, S. M., Margulis, B. A., Guzhova, I. V., Itskovich, V. B., Lauenroth, S., Müller, W. E. G., and Schröder, H. C.: Heat shock protein Hsp70 expression and DNA damage in Baikalian sponges exposed to model pollutants and wastewater from Baikalsk Pulp and paper plant, Aquat. Toxicol., 57, 267-280, 2002.

Ehrlich, H., Hanke, T., Simon, P., Goebel, C., Heinmann, S., Born, R., and Worch, H.: Demineralisation von natürlichen Silikatbasierten Biomaterialien: neue Strategie zur Isolation organischer Gerüststrukturen, BIOmaterialien, 6, 297-302, 2005.

Futuyma, D. J.: Evolutionary Biology, Sinauer Ass, Sunderland, 1986.

Garrone, R.: Evolution of metazoan collagens, Progr. Molec. Subcell. Biol., 21, 191-139, 1998.

Gehling, J. G. and Rigby J. K.: Long expected sponges from the Neoproterozoic Ediacara Fauna of South Australia, J. Paleontol., 70, 185-195, 1996.

Grotzinger, J. P., Bowring, S. A., Saylor, B., and Kauffmann, A. J.: New biostratigraphic and geochronologic constraints on early animal evolution, Science, 270, 598-604, 1995.

Haeckel, E.: Kunstformen der Natur, Bibliographisches Institut, Leipzig, 1899.

Hayes, J. M.: Global methanotrophy at the Archean-Proterozoic transition, in: Early Life on Earth, edited by Bengtson, S., Columbia University Press, New York, 220-236, 1994.

Hoffman, P. F., Kaufman, A. J., Halverson, G. P., and Schrag, D. P.: A Neoproterozoic snowball earth, Science, 281, 1342-1346, 1998.

Hoffmann, P. A. and Schrag, D. P.: The snowball Earth hypothesis: testing the limits of global change, Terra Nova, 129-155, 2002.

Knoll, A. H. and Carroll, S. B.: Early animal evolution: emerging views from comparative biology and geology, Science, 284, 2129-2137, 1999.

Krasko, A., Müller, I. M., and Müller, W. E. G.: Evolutionary relationships of the metazoan $\beta \gamma$-crystallins, including the one from the marine sponge Geodia cydonium, Proc. Royal Soci. Lond. B, 264, 1077-1084, 1997.

Krasko, A., Schröder, H. C., Hassanein, H. M. A., Batel, R., Müller, I. M., and Müller, W. E. G.: Identification and expression of the SOS-response, aidB-like, gene in the marine sponge Geodia cydonium: implication for the phylogenetic relationships of metazoan Acyl-CoA dehydrogenases and Acyl-CoA oxidases, J. Molec. Evol., 47, 343-352, 1998.

Krasko, A., Lorenz, B., Batel, R., Schröder, H. C., Müller, I. M., and Müller, W. E. G.: Expression of silicatein and collagen genes in the marine sponge Suberites domuncula is controlled by silicate and myotrophin, Europ. J. Biochem., 267, 4878-4887, 2000.

Krasko, A., Schröder, H. C., Batel, R., Grebenjuk, V. A., Steffen, R., Müller, I. M., and Müller, W. E. G.: Iron induces proliferation and morphogenesis in primmorphs from the marine sponge Suberites domuncula, DNA \& Cell Biol., 21, 67-80, 2002.

Krasko, A., Gundacker, D., Leys, S. P., Schröder, H. C., Müller, I. M., and Müller, W. E. G.: Molecular and functional analysis of the (6-4) photolyase from the hexactinellid Aphrocallistes vastus, Biochim. Biophys. Acta., 1651, 41-49, 2003.

Li, C. W., Chen, J. Y., and Hua T. E.: Precambrian sponges with cellular structures, Science, 279, 879-882 1998.

Morris, C. S.: The fossil record and the early evolution of the Metazoa, Nature, 361, 219-225, 1993.

Morris, C. S.: Why molecular biology needs palaeontology, De- velop. Suppl., 1-13, 1994.

Mostler, H.: Neue heteractinide Spongien (Calcispongea) aus dem Unter- und Mittelkambrium Südwestsardiniens, Ber. nat. med. Ver. Innsbruck, 72, 7-32, 1985.

Müller, W. E. G.: Origin of Metazoa: sponges as living fossils, Naturwiss., 85, 11-25, 1998.

Müller, W. E. G.: Spatial and temporal expression patterns in animals, in: Encyclopedia of Molecular Cell Biology and Molecular Medicine, edited by: Meyers, R. A., WILEY-VCH Press, Weinheim, 13, 269-309, 2005.

Müller, W. E. G.: The stem cell concept in sponges (Porifera): metazoan traits, Seminars in Cell \& Develop. Biol., 17, 481-491, 2006.

Müller, W. E. G. and Müller, I. M.: Origin of the metazoan immune system: Identification of the molecules and their functions in sponges, Integr. Comp. Biol., 43, 281-292, 2003.

Müller, W. E. G., Zahn, R. K., and Maidhof, A.: Spongilla gutenbergiana n.sp., ein Süßwasserschwamm aus dem Mittel-Eozän von Messel, Senckenbergiana lethaea, 63, 465-472, 1982.

Müller, W. E. G., Schröder, H. C., Skorokhod, A., Bünz, C., Müller, I. M., and Grebenjuk, V. A.: Contribution of sponge genes to unravel the genome of the hypothetical ancestor of metazoa (Urmetazoa), Gene, 276, 161-173, 2001.

Müller, W. E. G., Krasko, A., Le Pennec, G., Steffen, R., Ammar, M. S. A., Wiens, M., Müller, I. M., and Schröder, H. C.: Molecular mechanism of spicule formation in the demosponge Suberites domuncula: Silicatein - collagen - myotrophin, Progress Molec. Subcell. Biol., 33, 195-221, 2003.

Müller, W. E. G., Wiens, M., Adell, T., Gamulin, V., Schröder, H. C., and Müller, I. M.: The Bauplan of the Urmetazoa: The basis of the genetic complexity of Metazoa using the siliceous sponges [Porifera] as living fossils, Int. Rev. Cytol., 235, 53-92, 2004a.

Müller, W. E. G., Grebenjuk, V. A., Thakur, N. L., Thakur, A. N., Batel, R., Krasko, A., Müller, I. M., and Breter, H. J.: Oxygencontrolled bacterial growth in the sponge Suberites domuncula: Towards a molecular understanding of the symbiotic relationships between sponge and bacteria, Appl. Envir. Microbiol., 70, 2332-2341, 2004b.

Müller, W. E. G., Rothenberger, M., Boreiko, A., Tremel, W., Reiber, A., and Schröder, H. C.: Formation of siliceous spicules in the marine demosponge Suberites domuncula, Cell \& Tissue Res., 321, 285-297, 2005.

Müller, W. E. G., Belikov, S. I., Tremel, W., Perry, C. C., Gieskes, W. W. C., Boreiko, A., and Schröder, H. C.: Siliceous spicules in marine demosponges (example Suberites domuncula), Micron., 37, 107-120, 2006a.

Müller, W. E. G., Kaluzhnaya, O. V., Belikov, S. I., Rothenberger, M., Schröder, H. C., Reiber, A., Kaandorp, J. A., Manz, B., Mietchen, D., and Volke, F.: Magnetic resonance imaging of the siliceous skeleton of the demosponge Lubomirskia baicalensis, J. Struct. Biol., 153, 31-41, 2006b.

Müller, W. E. G., Wendt, K., Geppert, C., Wiens, M., Reiber, A., and Schröder, H. C.: Novel photoreception system in sponges? Unique transmission properties of the stalk spicules from the hexactinellid Hyalonema sieboldi, Biosensors and Bioelectronics, 21, 1149-1155, 2006c.

Müller, W. E. G., Schröder, H. C., Wrede, P., Kaluzhnaya, O. V., and Belikov, S. I.: Speciation of sponges in Baikal-Tuva region (an outline), J. Zool. Syst. Evol. Res., 44, 105-117, 2006d. 
Müller, W. E. G., Eckert, C., Kropf, K., Wang, X., Schloßmacher, U., Seckert, C., Wolf, S. E., Tremel, W., and Schröder, H. C.: Formation of the giant spicules of the deep sea hexactinellid Monorhaphis chuni (Schulze 1904): electron microscopic and biochemical studies, Cell \& Tissue Res., doi:10.1007/s00441007-0402-x, 2007.

Nichols, S. A., Dirks, W., Pearse, J. S., and King, N.: Early evolution of animal cell signaling and adhesion genes. Proc. Natl. Acad. Sci. USA, 103, 12 451-12 456, 2006.

Pancer, Z., Kruse, M., Müller, I., and Müller, W. E. G.: On the origin of adhesion receptors of metazoa: cloning of the integrin $\alpha$ subunit cDNA from the sponge Geodia cydonium, Molec. Biol. Evol., 14, 391-398, 1997.

Pasteur, L.: Mémoire sur la fermentation appelée lactique, Mém, Soc. Sci. Agric et Arts, 5, 13-26, 1857.

Perović-Ottstadt, S., Adell, T., Proksch, P., Wiens, M., Korzhev, M., Gamulin, V., Müller, I. M., and Müller, W. E. G.: A (1 $\rightarrow 3)$ $\beta$-d-glucan recognition protein from the sponge Suberites domuncula: mediated activation of fibrinogen-like protein and epidermal growth factor gene expression, Eur. J. Biochem., 271, 1924-1937, 2004a.

Pechenik, J. A.: Biology of the Invertebrates, McGraw Hill, Boston, 2000.

Pilcher, H.: Back to our roots, Nature, 435, 1022-1023, 2005.

Pfeifer, K., Haasemann, M., Gamulin, V., Bretting, H., Fahrenholz, F., and Müller, W. E. G.: S-type lectins occur also in invertebrates: high conservation of the carbohydrate recognition domain in the lectin genes from the marine sponge Geodia cydonium, Glycobiol., 3, 179-184, 1993.

Pilcher, H.: Back to our roots, Nature, 435, 1022-1023, 2005.

Reitner, J.: Coralline Spongien. Der Versuch einer phylogenetischtaxonomischen Analyse, Berliner Geowiss. Abh. (E), 1, 1-352, 1992.

Reitner, J. and Mehl, D.: Early Paleozoic deversification of sponges: New data and evidences, Geol. Paläont. Mitt. Innsbruck, 20, 335-347, 1995.

Reitner, J. and Wörheide, G.: Non-Lithistid fossil Demospongiae Origins of their Palaeobiodiversity and Highlights in History of Preservation, in: Systema Porifera: A Guide to the Classification of Sponges, edited by: Hooper, J. N. A. and Van Soest, R., Kluwer, New York, pp. 52-68, 2002.

Retallack, G. J.: Were the Ediacaran fossils lichens?, Paleobiology, 20, 523-544, 1994.

Rigby, J. K. and Hou, Xian-Guang.: Lower Cambrian demosponges and hexactinellid sponges from Yunnan, China, J. Paleont., 69, 1009-1019, 1995.

Sanford, F.: Physical and chemical analysis of the siliceous skeleton in six sponges of two groups (Demospongiae and Hexactinellida), Micr. Res. Techn., 62, 336-355, 2003.

Schütze, J., Custodio, M. R., Efremova, S. M., Müller, I. M., and Müller, W. E. G. Evolutionary relationship of metazoa within the eukaryotes based on molecular data from Porifera, Proc. Roy. Soc. Lond. B, 266, 63-73, 1999.

Schröder, H. C., Krasko, A., Ushijima, H., Gamulin, V., Schütze, J., Müller, I. M., and Müller, W. E. G.: Emergence and disappearance of an immune molecule, an antimicrobial lectin, in basal Metazoa: the tachylectin family, J. Biol. Chem., 278, 32810 $32817,2003 a$.

Schröder, H. C., Krasko, A., Le Pennec, G., Adell, T., Wiens, M.,
Hassanein, H., Müller, I. M., and Müller, W. E. G.: Silicase, an enzyme which degrades biogenous amorphous silica: Contribution to the metabolism of silica deposition in the demosponge Suberites domuncula, Prog. Mol. Subcell. Biol., 33, 250-268, 2003 b.

Schröder, H. C., Perović-Ottstadt, S., Rothenberger, M., Wiens, M., Schwertner, H., Batel, R., Korzhev, M., Müller, I. M., and Müller, W. E. G.: Silica transport in the demosponge Suberites domuncula: fluorescence emission analysis using the PDMPO probe and cloning of a potential transporter, Biochem. J., 381, $665==673,2004 \mathrm{a}$.

Schröder, H. C., Perovi-Ottstadt, S., Wiens, M., Batel, R., Müller, I. M., and Müller, W. E. G.: Differentiation capacity of the epithelial cells in the sponge Suberites domuncula, Cell \& Tissue Res., $316,271==280,2004 b$.

Schröder, H. C., Boreiko, A., Korzhev, M., Tahir, M. N., Tremel, W., Eckert, C., Ushijima, H., Müller, I. M., and Müller, W. E. G.: Co-Expression and functional interaction of silicatein with galectin: matrix-guided formation of siliceous spicules in the marine demosponge Suberites domuncula, J. Biol. Chem., 281, 12 001-12 009, 2006.

Schröder, H. C., Brandt, D., Schloßmacher, U., Wang, X., Tahir, M. N., Tremel, W., Belikov, S. I., and Müller, W. E. G., Enzymatic production of biosilica-glass using enzymes from sponges: Basic aspects and application in nanobiotechnology (material sciences and medicine), Naturwissenschaften, 94, 339-359, 2007.

Schulze, F. E.: Hexactinellida. Wissenschaftliche Ergebnisse der Deutschen Tiefsee-Expedition auf dem Dampfer "Valdivia" 1898-1899, Gustav Fischer Verlag, Stuttgart, pp. 1-266, 1904.

Seilacher, A.: Vendozoa: Organismic construction in the proterozoic biosphere, Lethaia, 22, 229-239, 1989.

Shimizu, K., Cha, J., Stucky, G. D., and Morse, D. E.: Silicatein alpha: cathepsin L-like protein in sponge biosilica, Proc. Natl. Acad. Sci. USA, 95, 6234-6238, 1998.

Sly, W. S. and Hu, P. Y.: Human carbonic anhydrases and carbonic anhydrase deficiencies, Annu. Rev. Biochem., 64, 375401, 1995.

Steiner, M., Mehl, D., Reitner, J., and Erdtmann, B. D.: Oldest entirely preserved sponges and other fossils from the Lowermost Cambrian and a new facies reconstruction of the Yangtze Platform (China), Berliner Geowiss. Abh. (E), 9, 293-329, 1993

Steiner, M.: Die Neoproterozoischen Megaalgen Südchinas, Berliner Geowiss. Abh., 15, 100146, 1994.

Thakur, N. L., Perovi-Ottstadt, S., Batel, R., Korzhev, M., DiehlSeifert, B., Müller, I. M., and Müller, W. E. G.: Innate immune defense of the sponge Suberites domuncula against grampositive bacteria: induction of lysozyme and AdaPTin, Mar. Biol., 146, 271-282, 2005.

Towe, K. M.: Environmental conditions surrounding the origin and early evolution of life, Precambrian Res., 16, 10010, 1981.

Towe, K. M.: Oxygen-collagen priortiy and the metzoan fossil record, Proc. Natl. Acad. Sci. USA, 65, 78100788, 1970.

Uriz, M. J., Turon, X., and Becerro, M. A.: Silica deposition in Demospongiae: spiculogenesis in Crambe crambe, Cell \& Tissue Res., 301, 299-309, 2000.

Uriz, M. J., Turon, X., and Beccero, M. A.: Silica deposition in demosponges, Progr. Molec. Subcell. Biol., 33, 163-193, 2003.

Uriz, M. J.: Mineral skeletogenesis in sponges, Canadian J. Zool., 84, 322-356, 2006. 
Wang, X. and Wang, Y.: An introduction to the study on natural characteristics of sponge spicules and bionic applications, Adv. Earth Sci., 21, 37-42, 2006.

Wang, X., Li, J., Qiao, L., Schröder, H. C., Eckert, C., Kropf, K., and Müller, W. E. G.: The giant spicules of the deep sea hexactinellidan sponges of the genus Monorhaphis (Hexactinellida: Amphidiscosida: Monorhaphididae), Acta Zoologica Sinica, in press, 2007.

Walker, G.: Snowball Earth: The Story of the Great Global Catastrophe that Spawned Life as we Know it, Crown Publishers, New York, 2003.

Wiens, M. and Müller, W. E. G.: Cell death in Porifera: molecular players in the game of apoptotic cell death in living fossils, Can. J. Zool./Rev. Can. Zool., 84, 307-321, 2006.

Wiens, M., Mangoni, A., D’Esposito, M., Fattorusso, E., Korchagina, N., Schröder, H. C., Grebenjuk, V. A., Krasko, A., Batel, R., Müller, I. M., and Müller, W. E. G.: The molecular basis for the evolution of the metazoan bodyplan: extracellular matrixmediated morphogenesis in marine demosponges, J. Mol. Evol., 57, 1-16, 2003.
Wiens, M., Perovi-Ottstadt, S., Müller, I. M., and Müller, W. E. G.: Allograft rejection in the mixed cell reaction system of the demosponge Suberites domuncula is controlled by differential expression of apoptotic genes, Immunogenetics, 56, 597-610, 2004.

Wiens, M., Korzhev, M., Krasko, A., Thakur, N. L., PeroviOttstadt, S., Breter, H. J., Ushijima, H., Diehl-Seifert, B., Müller, I. M., and Müller, W. E. G.: Innate immune defense of the sponge Suberites domuncula against bacteria involves a MyD88-dependent signaling pathway: induction of a perforinlike molecule, J. Biol. Chem., 280, 27 949-27 959, 2005.

Wiens, M., Belikov, S. I., Kaluzhnaya, O. V., Krasko, A., Schröder, H. C., Perovic-Ottstadt, S., and Müller, W. E. G.: Molecular control of serial module formation along the apical-basal axis in the sponge Lubomirskia baicalensis: silicateins, mannose-binding lectin and Mago Nashi, Develop. Genes Evol., 216, 229-242, 2006.

Wöhler, F.: Ueber künstliche Bildung des Harnstoffs, Annalen der Physik und Chemie, 12, 253-256, 1828. 